\title{
Technè
}

La science au service de l'histoire de l'art et de la préservation des biens culturels

48 | 2019

Les couleurs de l'Antique

\section{La $8^{\mathrm{e}}$ table ronde sur la polychromie antique (Paris, 2016) \\ Introduction}

Brigitte Bourgeois, Violaine Jeammet et Francis Prost

\section{(2) OpenEdition}

Journals

Édition électronique

URL : https://journals.openedition.org/techne/1691

DOI : 10.4000/techne.1691

ISSN : 2534-5168

Traduction(s) :

The 8th round table on ancient polychromy (Paris, 2016) - URL : https://journals.openedition.org/ techne/1707 [en]

Éditeur

C2RMF

Édition imprimée

Date de publication : 31 décembre 2019

Pagination : 4-5

ISBN : 978-2-11-152831-4

ISSN : $1254-7867$

\section{Référence électronique}

Brigitte Bourgeois, Violaine Jeammet et Francis Prost, « La 8 e table ronde sur la polychromie antique (Paris, 2016) », Technè [En ligne], 48 | 2019, mis en ligne le 01 juillet 2021, consulté le 03 avril 2022. URL : http://journals.openedition.org/techne/1691 ; DOI : https://doi.org/10.4000/techne.1691

\section{c) $(1) \Theta$}

La revue Technè. La science au service de l'histoire de l'art et de la préservation des biens culturels est mise à disposition selon les termes de la Licence Creative Commons Attribution - Pas d'Utilisation Commerciale - Pas de Modification 4.0 International. 
Brigitte Bourgeois Violaine Jeammet Francis Prost

\section{La $8^{\mathrm{e}}$ table ronde sur la polychromie antique (Paris, 2016)}

\section{Introduction}

The 8th round table on ancient polychromy (Paris, 2016)
Les 15 et 16 novembre 2016, devant un public fourni, le Centre de recherche et de restauration des musées de France (C2RMF) a accueilli la huitième rencontre du réseau international sur la polychromie antique, organisée avec le soutien de l'université Paris I-Panthéon Sorbonne et de l'École française d'Athènes. Après Copenhague, Londres, Francfort, Athènes et Florence, le choix de Paris s'était imposé naturellement comme un lieu propice aux échanges, étant donné la contribution active de la France à ce domaine de recherche et, depuis plus de vingt ans, la forte implication scientifique du C2RMF dans les travaux sur la couleur. Pour mieux rendre compte d'ailleurs de la vitalité des recherches menées en partenariat entre le musée du Louvre et le Centre de recherche, la rencontre a été couplée avec la tenue, les 17 et 18 novembre, de la Journée d'étude internationale Terres cuites grecques et romaines : vingt ans d'étude et de restauration, organisée à l'initiative du département des Antiquités grecques, étrusques et romaines du musée du Louvre (V. Jeammet). Celle-ci a permis de présenter notamment le programme de recherche Pilina (Polychromie antique sur argile), consacré aux pratiques artisanales de la couleur sur les figurines en terre cuite grecques $^{1}$. Notre collègue Sandrine Pagès-Camagna, malheureusement trop tôt disparue, en avait assuré le pilotage ; nous saluons ici sa mémoire.

Sur un sujet encore aussi méconnu que l'est la polychromie antique, la question de la dissémination et de l'accessibilité des recherches sous une forme pérenne s'avère cruciale. Le C2RMF a pris à cour de relever ce défi en décidant de publier la rencontre en version imprimée, tout comme les organisateurs de deux précédentes tables rondes (Athènes et Florence) l'ont entrepris ${ }^{2}$. Malgré des difficultés imprévues, le projet a été mené à bien et la revue Technè rassemble donc dans ce numéro la plupart des communications présentées à l'automne 2016, complétées par une rubrique de Varia portant également sur la couleur. Sans le soutien décisif d'Isabelle Pallot-Frossard, directeur du C2RMF, et du comité de rédaction de Technè, cette publication n'aurait pu voir le jour dans des conditions aussi favorables. Nous tenons à les en remercier chaleureusement.

Éditée désormais en double format, électronique et papier, la revue Technè bénéficie d'une visibilité accrue grâce à son tout récent rattachement au portail de diffusion OpenEdition Journals (précédemment revues.org). C'est dire si le rayonnement des travaux de la table ronde parisienne devrait être large. Ce double support pour diffuser les travaux sur la polychromie antique est comme la métaphore de la double mission que se fixe cette recherche : elle sait mobiliser des technologies de plus en plus fines pour dévoiler les couleurs des œuvres antiques, leur intensité, les procédés de leur mise en œuvre et l'étendue scientifiquement démontrée de leur utilisation ; elle sait aussi reconstituer des contextes, des histoires, des thématiques, des cadres économiques et politiques, l'environnement des objets qu'elle étudie et dont elle souhaite définir la portée. Façon de faire et façon de voir, science et histoire : puissent toutes les couleurs de Technè trouver leur lecteur!

\section{Notes}

1. Le programme Pilina (LouvreC2RMF), mené en 2014-2015 avec le soutien financier de la Fondation des Sciences du Patrimoine (LabEx Patrima) et repris depuis lors (2018-2020), est en voie d'achèvement et donnera lieu à une publication collective. 2. Voir S. Bracci, G. Giachi, P. Liverani, P. Pallecchi, F. Paolucci (eds.), Polychromy in Ancient Sculpture and Architecture, Florence, Sillabe, 2018. Et à paraître H. Brecoulaki (ed.), Archaeology of Colour. Technical Studies in Greek and Roman painting and polychromy, Athens, 2020

Brigitte Bourgeois, conservatrice générale du patrimoine, rédactrice en chef de la revue Technè, C2RMF (brigitte.bourgeois@culture. gouv.fr). Violaine Jeammet, conservatrice générale du patrimoine, département des Antiquités grecques, étrusques et romaines, musée du Louvre (violaine.jeammet@louvre.fr). Francis Prost, professeur d'archéologie classique, université Paris I - Panthéon Sorbonne, UMR 7041 ArScAn (Francis.Prost@univ-paris1.fr). 
On 15-16 November 2016, in front of a large audience, the Centre de Recherche et de Restauration des Musées de France (C2RMF) hosted the eighth international round table on ancient polychromy, organized with the support of the Université Paris I-Panthéon Sorbonne and the École française, Athens. After Copenhagen, London, Frankfurt, Athens and Florence, Paris seemed the natural choice for a venue conducive to discussion, given France's active contribution to this field of research and the C2RMF's scientific involvement in work on colour for over twenty years. To better appreciate the liveliness of the research jointly undertaken by the Louvre museum and the C2RMF, the round table was followed, on 17-18 November, by two days of study on the scientific research and restoration of Greek and Roman terracottas (Terres cuites grecques et romaines : vingt ans d'étude et de restauration), organized on the initiative of the Louvre's Department of Greek, Etruscan and Roman Antiquities (V. Jeammet). The event notably enabled us to present the research project Pilina (Ancient Polychromy on Clay), focusing on craftsmen's use of colour on Greek terracotta figurines ${ }^{1}$. Our sadly departed colleague Sandrine Pagès-Camagna was the project manager; we pay tribute to her memory here.

On a subject still as little known as ancient polychromy, the question of dissemination and accessibilty of the research findings in a durable form is crucial. The C2RMF has risen to the challenge, by deciding to publish the main results of the round table in a printed version, as did the hosts of two past events (Athens and Florence) ${ }^{2}$. In spite of unexpected difficulties, the project has been carried out successfully and the Technè journal has thus included in this issue most of the papers presented in autumn 2016, together with a section of miscellaneous items also on colour. Without the decisive backing of the C2RMF director, Isabelle Pallot-Frossard, and Technès editorial board, this publication would never have come out in such favourable conditions. We would like to offer them our warmest thanks.

From now on issued in both electronic and printed format, Technè will benefit from greater visibility thanks to its recent membership of the dissemination portal OpenEdition Journals (formerly revues.org). Which means that the influence of the Parisian round table's work should be widespread. This twofold manner of disseminating the work on ancient polychromy is like a metaphor for the twofold objective of this research: first, to employ increasingly refined technology to reveal the colours of ancient works, as well as their intensity, implementation and the scientifically proven extent of their use; second, to reconstruct the context, economic and political background, history, themes and environment of the objects under investigation whose agency this research seeks to define. Ways of doing in the past and ways of looking at the past, science and history: may all the colours in Technè find their reader!

Notes

1. The "Pilina" project (LouvreC2RMF), conducted in 2014-2015 with the financial support of the Fondation des Sciences du Patrimoine (LabEx Patrima) and since resumed (2018-2020), is in the completion stage and will give rise to a collective publication.

2. See S. Bracci, G. Giachi, P. Liverani, P. Pallecchi, F. Paolucci (eds.), Polychromy in Ancient Sculpture and Architecture, Florence,
Sillabe, 2018. Due out soon H. Brecoulaki (ed.), Archaeology of Colour. Technical Studies in Greek and Roman Painting and Polychromy, Athens, 2020. 